\title{
中国福州市における成人男子の体組成に関する研究
}

劉 景瑜* 田中 茂穂** 林 敦玉***

\section{Research on Body Composition in Adult Males in Fuzhou, P.R. of China}

\section{LIU Jing Yu*, Shigeho TANAKA** and LIN Dunyu***}

Using 6 skinfold thicknesses (triceps, subscapular, abdomen, suprailiac, anterior thigh, posterior calf) measured by B-mode ultrasound technique, subcutaneous fat distribution was assessed and percentage of body fat was measured by near infrare spectroscopy in 55 Chinese adult males in Fuzhou aged from 20 to 40 years. The results are as follows:

1. Subcutaneous fat distribution pattern is the same as the reports that subcutaneous fat is the thickest in abdomen and the thinnest in limbs. Compared with studies of American and Japanese, the subcutaneous fat of Chinese males was thicker in suprailiac and posterior calf, and thinner in subscapular.

2. Percentage of body fat or total body fat was moderately positively correlated with skinfold thickness.

Key words : Chinese, body composition, B-mode ultrasound, near infrared spectroscopy 中国人，体組成，Bモード式超音波法，近赤外線法

\section{I 序論}

近年, 中国の経済発展と共に国民生活水準が上 昇し，エネルギーの過利摄取も増え始め，それに 伴って肥満者が増加してくると予想される. 肥満 は, 成人病のリスクファクターの一つとして注目 されており, 特に, 体脂肪の分布が成人病と深い 関連を持つことが，多くの研究により明らかと
なってきている（S. Fujiokaほか，1987；A.H. Kissebah ほか, 1982 ; J.P. Desprès ほか, 1990). 近い将来, 中国で肥満が大きな問題に発展するこ とは間違いなく，したがって，現在の中国の状況 を把握しておくことは重要である。

従来, 間接的に体脂肪量を測定する方法として, 体密度法(水中体重法)，体水分法，カリウム -40 法, 近赤外線法, X 線法, 骨密度法, 生体インピー

*東京大学大学院教育学研究科総合教育科学専攻体育科学コース

**茨城大学教養部保健体育学教室

***中国福建省福州市第二医院超音波室

*Department of Exercise, Sports, and Health Sciences, The University of Tokyo Graduate School of Education

**Faculty of General Education, Ibaraki University

*** Section of Ultrasound Research, Fuzhou 2nd Municipal Hospital, Fujian Province, P.R. of China 
ダンス法, CT 法, MRI 法, 皮下脂肪厚から算出 する方法などが用いられてきた。しかし，カリウ ム-40法, 骨密度法, CT 法, MRI 法などは費用 がかかり, 大がかりな装置が必要であり, 発展途 上国で応用するのは難しい. 超音波 B モード装置 は, $\mathrm{X}$ 線法や CT 法と同様, 直接皮下脂肪組織の 断層面を観察でき，しかも X 線の被曝の問題がな い.また，超音波 B モード法と CT スキャン法の 測定值の間には，0.97から0.99までの非常に高い 相関係数が報告されており（福永哲夫ほか, 1990), 妥当性の点でも優れている。一方, 近赤外線体脂 肪測定器は, 測定の精度, 客観性, 再現性, 簡便 性が優れ，被検者の負担が少ない(大野誠，1992) などの点から, フィールドでの応用の可能性があ るものとして関心がもたれている.そこで本研究 では，B モード式超音波法扔よび近赤外分光法体 脂肪測定器を用いて, 中国福建省, 福州市第二病 院に勤務している成人男子55名を対象に皮下脂肪 厚の分布を調べ，また，本研究の結果と日本およ び米国の先行研究の結果を比較した.

\section{II 対象および方法}

被検者は中国の東南沿海にある福建省, 福州市 第二病院に勤務している健康な医師，技師ら男子 55 名で, 年齢は 20 歳から 40 歳であった. 身長, 体 重の他, 四肢では上腕後部, 大腿前部, 下腿前後 の 3 部位と, 体幹では肩甲骨下部, 腹部, 腸骨棘 上部の 3 部位計 6 部位の皮下脂肪厚を測定した。 測定はいずれも身体の右側で行った．詳細は，以 下の通りである（保志宏，1989）

上腕後部：上腕後部で肩峰と肘頭との中央部. 大腿前部：大腿前面で鼠径部と膝蓋骨との中 間.
下腿後部：下腿最大囲測定レベルで下腿後面中 央線の部位.

肩甲骨下部：肩甲骨下角直下 $2 \mathrm{~cm}$ の部位.

腹部：臍の高さで臍の外側方 $2 \sim 3 \mathrm{~cm}$ の部位.

腸骨棘上部：上前腸骨棘の上方 $1 \mathrm{~cm}$ の部位. 皮下脂肪厚の測定には，アロカ社製の超音波診断 装置 SSD-650型を使用した，皮下脂肪厚は，石田 ほか（1989）の研究と同じ方法で，表皮より皮下 脂肪組織と筋組織の境界面までの距離を皮下脂肪 厚として測定した。

また，ケット科学研究所の近赤外分光法体脂肪 測定器 BFT-2000を用いて, 体脂肪率を推定した. 体脂肪量は, 体重に体脂肪率を乗じたものとした。 測定は遮光帯で覆ったプローブを被検者の右上腕 二頭筋の筋腹の頂点に垂直に軽く押し当て, 波長 947nm の近赤外線を用いて行った.

測定期間は1993年 8 月28日からの 1 週間であっ た.

統計解析は東京大学大型計算機センターにおい て, 統計解析パッケージ SAS を用いて, 20歳代と 30 歳代両グループ間の平均值間の有意性を $\mathrm{t}$ 検定 により検討した。 また, 日, 米との比較研究中, 本研究の 20 歳代のグループの被検者の各部位の皮 下脂肪厚の值と Y. Ishida ほか (1992), 及び石田 ほか (1989) の值とでそれぞれ $\mathrm{t}$ 検定を行った（市 川伸一ほか, 1987)。

\section{III 結 果}

表 1 に,本研究の被検者の身体的特徵を示した。 体重と BMI は30歳代グループの方が有意に高い 值が認められた。

表 2 に, 本研究の被検者における身体 6 部位の 皮下脂肪厚の平均値と標準偏差を示した。皮下脂

表 1 中国福州市成人男性の形態的特徵（平均值および標準偏差）

\begin{tabular}{|c|c|c|c|c|c|}
\hline $\begin{array}{l}\text { 年 齢 } \\
\text { (歳) }\end{array}$ & $\begin{array}{l}\text { 被検者数 } \\
\text { (人) }\end{array}$ & $\begin{array}{l}\text { 身 長 } \\
(\mathrm{cm})\end{array}$ & $\begin{array}{c}\text { 体 重 } \\
(\mathrm{kg})\end{array}$ & $\underset{\mathrm{kg} / \mathrm{cm}^{2}}{\mathrm{BMI}}$ & $\begin{array}{c}\text { 体脂肪率 } \\
(\%)\end{array}$ \\
\hline $20 \sim 29(24.8 \pm 3.4)$ & 33 & $168.9 \pm 6.0$ & $57.7 \pm 7.4^{* *}$ & $20.2 \pm 2.0^{*}$ & $11.3 \pm 4.5$ \\
\hline $30 \sim 40(33.3 \pm 3.4)$ & 22 & $169.8 \pm 4.0$ & $63.8 \pm 10.0$ & $22.0 \pm 2.9$ & $12.9 \pm 5.4$ \\
\hline
\end{tabular}


表 2 本研究の成人男性の 6 部位皮下脂肪厚の平均值 $(\mathrm{mm})$ 土標準偏差及び体脂肪量 $(\mathrm{kg})$

\begin{tabular}{cccccccc}
\hline 年齢(歳) & $\mathrm{TC}$ & $\mathrm{SS}$ & $\mathrm{AB}$ & \multicolumn{1}{c}{$\mathrm{SI}$} & $\mathrm{AT}$ & $\mathrm{PC}$ & $\mathrm{TBF}$ \\
\hline $20 \sim 29$ & $5.7 \pm 1.9^{*}$ & $5.6 \pm 1.5^{*}$ & $11.3 \pm 4.3$ & $9.3 \pm 1.6$ & $6.9 \pm 1.8$ & $6.4 \pm 2.3$ & $6.7 \pm 3.2$ \\
$30 \sim 40$ & $7.4 \pm 3.1$ & $6.7 \pm 1.8$ & $14.9 \pm 7.0$ & $10.2 \pm 4.7$ & $8.3 \pm 3.5$ & $7.1 \pm 2.2$ & $8.6 \pm 5.0$ \\
\hline
\end{tabular}

$\mathrm{TC}$ ：上腕後部 $\mathrm{SS}$ ：肩甲骨下部 $\mathrm{AB}$ ：臍横部 $\mathrm{SI}$ ：腸骨棘上部 $\mathrm{AT}$ ：大腿前部 $\mathrm{PC}$ ：下腿後部 $\mathrm{TBF}:$ 体脂肪量 ${ }^{*} \mathrm{p}<0.05$

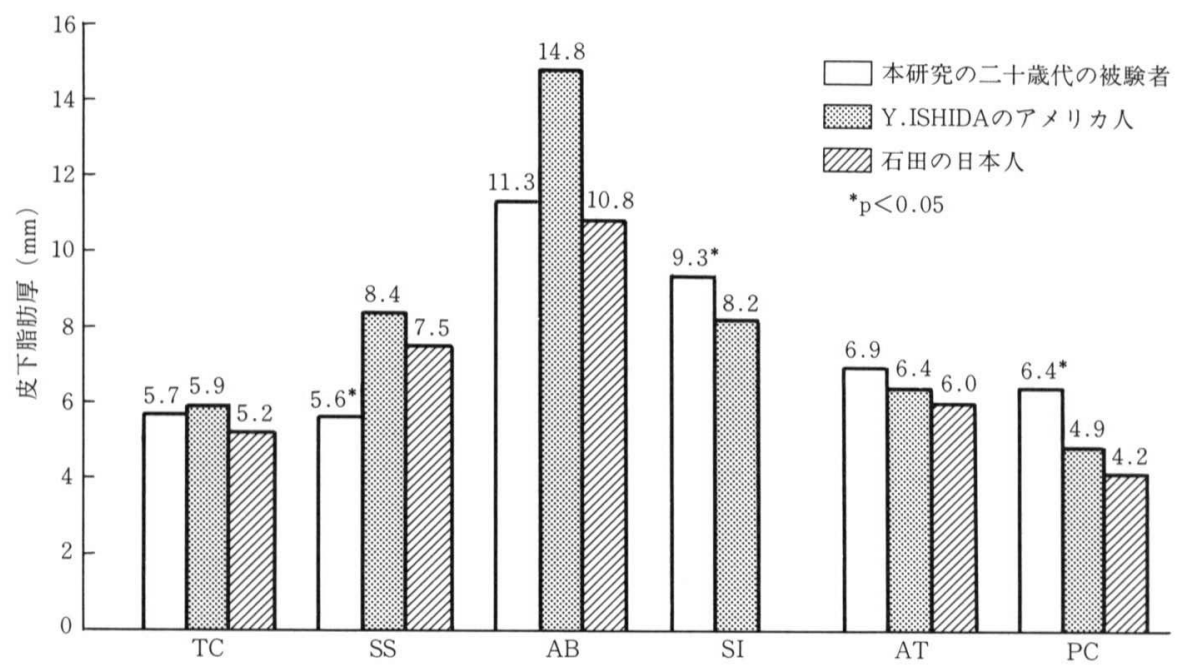

図 1 本研究の成人男性の皮下脂肪厚と他の報告との比較

肪厚の分布パターンについて, 両グループとも体 幹下部および大腿部の皮下脂肪厚が厚く, 体幹上 部と体幹に遠位な部位ほど小さくなる傾向にあっ た。しかし，全体的に見ると，20歳代の被検者の 皮脂厚の值より 30 歳代の方が上昇する傾向であっ たが，とくに，上腕後部，肩甲骨下部の両部位に 有意に高い值が認められた。

図 1 は, 本研究の 20 歳代の被検者の測定結果と 日本人男性を対象とした研究（石田ほか，1989） および米国人男性を対象とした研究結果 (Y. Ishida ほか，1992）とを比較したものである. 図 1 から分かるように, 石田らの研究では SI の部位 を測定しなかったが，本研究の被検者における 6 部位の皮下脂肪厚の和は Y. Ishida らの被検者の とほほ同じで，それぞれ 46.2 と $48.6 \mathrm{~mm}$ であった が, 各部位の皮下脂肪厚の值から見ると先行研究 の結果より腸骨棘上部, 下腿後部の方が有意にや
や大きく, 肩甲骨下部の方が有意に小さい值で あった。

近赤外分光法による体脂肪率および体脂肪量の 平均値と標準偏差は, それぞれ20歳代グループで は11.3土4.5\%, $6.7 \pm 3.2 \mathrm{~kg}, 30$ 歳代グループでは $12.9 \pm 5.4 \%, 8.6 \pm 5.0 \mathrm{~kg}$ であり, 有意差がなかっ た. 体脂肪率及び体脂肪量と, 身体的特徵および 皮下脂肪厚の測定值の相関分析の結果を表 3 に示 した. 体脂肪率と皮下脂肪厚の間の相関係数は 20 歳代と 30 歳代それぞれ0.34 0.52と0.49〜0.69 で, 体脂肪量と皮下脂肪厚の間の相関係数もそれ ぞれ0.34〜0.52 と0.51〜0.70で，正の相関がみら れた。

\section{IV 考察}

中国全国の調査の福建省の結果 (91中国学生体 質与健康研究組編，1993）によると19から22歳ま 
表 3 本研究の成人男性の体脂肪率と皮下脂肪厚等との相関係数

\begin{tabular}{lccccccccccc}
\hline & & 年齢 & 体重 & 身長 & BMI & TC & SS & AB & SI & AT & PC \\
\hline 20 歳代 & $\mathrm{PTBF}$ & $0.37^{*}$ & $0.56^{* *}$ & 0.11 & $0.67^{* *}$ & 0.30 & $0.52^{* *}$ & 0.30 & $0.34^{*}$ & $0.38^{*}$ & 0.31 \\
グループ & $\mathrm{TBF}$ & $0.41^{* *}$ & $0.72^{* *}$ & 0.23 & $0.79^{* *}$ & 0.28 & $0.52^{* *}$ & 0.29 & $0.34^{*}$ & $0.40^{*}$ & 0.27 \\
\hline 30 歳代 & $\mathrm{PTBF}$ & 0.22 & $0.76^{* *}$ & 0.35 & $0.77^{* *}$ & $0.49^{* *}$ & $0.56^{* *}$ & $0.69^{* *}$ & $0.66^{* *}$ & $0.50^{* *}$ & $0.64^{* *}$ \\
グループ & $\mathrm{TBF}$ & 0.28 & $0.87^{* *}$ & 0.39 & $0.89^{* *}$ & $0.57^{* *}$ & $0.59^{* *}$ & $0.68^{* *}$ & $0.70^{* *}$ & $0.51^{* *}$ & $0.66^{* *}$ \\
\hline $\mathrm{PTBF}:$ 体脂肪率 & $\mathrm{TBF}:$ 体脂肪量 & $\mathrm{TC}:$ 上腕後部 & $\mathrm{SS}:$ 肩厚骨下部 & $\mathrm{AB}:$ 臍横部 & $\mathrm{SI}:$ 腸骨梀上部 \\
$\mathrm{AT}:$ 大腿前部 & $\mathrm{PC}:$ 下腿後部 & $* \mathrm{p}<0.05$ & ${ }^{* *} \mathrm{p}<0.01$ & & & & & &
\end{tabular}

での男性の平均身長と体重はそれぞれ169.7 55.9 $\mathrm{cm}, 57.1 \pm 5.7 \mathrm{~kg}$ であり, 本研究の 20 歳代の被検 者の平均值とほぼ一致している。年齢は厳密に対 応していないが，22歳以後の標準值は存在せず， この程度の年齢差では大きな変化は考えにくいこ とから, 本研究の 20 歳代の被検者群は, 中国福建 省の 20 歳代の平均に近い標準的な集団とみなして よいであろう。

本研究の被検者の皮下脂肪の分布パターンにつ いては腹部，体幹下部および大腿部の皮下脂肪厚 が厚く，体幹上部や体幹に遠位な部位ほど小さく なる傾向にある．これは既に報告されている結果 と同様であった(福永ほか，1990)。同一個人の身 体部位によって, 皮脂厚が異なる原因について $\mathrm{M}$. Rebuffè-Scrive ほか（1989）はそれぞれの部位に 存在している脂肪細胞の生理学的特徵によるもの としている，それによると，腹部や层部のように 体幹の下方の部分にある脂肪細胞は，体肢に比心゙ て代謝が活発であるという. M. Rebuffè-Scrive らは, 皮下脂肪の厚さを決める要因の 1 つはその 部位に存在する脂肪細胞の大きさであり，これは 細胞の代謝活動能力によって決定されることを示 唆するものとしている.また, T.O. Rognum ほか （1982）は，青年を対象に，食事制限と身体運動に よって激しいエネルギー消耗を起こさせた研究の 結果より, 腹部や㑑部の脂肪細胞より体肢の脂肪 細胞の方が脂肪分解の感受性が弱いことがわかっ た. 以上のような点が, 本研究にみられる皮下脂 肪厚分布パターンを招いたと考えられる.

本研究の結果と比較した石田らの被検者及び Y. Ishida らの被検者はいずれも, 運動選手ではな
い健康な成人であった．石田らの被検者の数は 35 名で, 年齢, 身長, 体重はそれぞれ $24 \pm 6.7$ 歳, $170.5 \pm 6.5 \mathrm{~cm}, 63.3 \pm 7.4 \mathrm{~kg}$ であった。また，Y Ishida らの被検者の数は17名で, 年齢が $26.9 \pm$ 4.4歳であった(身長, 体重の值は揭載されていな かった). 皮下脂肪の值については, 本研究の測定 方法および測定部位が Y. Ishida らおよび石田ら のものとほぼ一致しているので, 比較することが 出来る. Y. Ishida らおよび石田らの值より, 本研 究の被検者の腸骨棘上部と下腿後部の二部位の値 が高く，肩甲骨下部の值が低い。ただし，腸骨棘 上部の部位については, 石田らの研究では測定し なかったが, Y. Ishida らは前腋筒からの垂直線 と腸骨棱の交点という, 本研究の測定部位よりや や外上方で測定を行っている。 なお，湯浅ほか （1987）は，二人の日本人男性を対象に B モード方 式で体幹と体肢の異なった 351 箇所の皮下脂肪を 測定した。その結果, 皮下脂肪が厚い箇所は, 臍 を中心とした腹部および乳頭下から体側にかけて の部分であり，また，肢体における皮脂厚は体幹 のそれに比べて薄く，かつ均一に分布する様相と している.ということは，Y. Ishida の腸骨棘上部 の皮下脂肪厚が, 本研究の腸骨棘上部より大きく なるはずである。即ち, 本研究の腸骨棘上部の測 定部位とY. Ishida のと同じなら, 本研究の測定 值の方が大きくなると推定できる，また，上腕後 部, 大腿前部, 下腿後部三部位の測定上 $2.5 \mathrm{~cm}$ 前 後ずれるが，湯浅らの結論より，それによる部位 差が大きいとは考えられない.

廖恵珍ほか（1991）によると，1988年福建省に おける食物，栄養構成の調査では，一日平均一人 
あたり食物から得るカロリーは2,376 kcal, 蛋白質 が52.70g, 脂肪が $41.90 \mathrm{~g}$ である. 総カロリーの中 で三大栄養素のエネルギー提供比率は炭水化合物 の $75 \%$ : 蛋白質の $9 \%$ ：脂肪の $16 \%$ であり, 蛋白 質と脂肪の量はやや低い。本研究の被検者におい て腸骨棘上部と下腿後部の值が大きく, 肩甲骨下 部の值が小さい原因は明らかにできないが, 石田 （1994）は皮下脂肪厚の分布は体脂肪の総量に比べ 遺伝による影響が大きいと推測しており，さらに， 人種によっても異なることが報告されている（R. N.J. Pierson ほか, 1990).

また，気温に対する適応の体形づくりによる体 表面積の変化は古くから論じられている（伊藤広 三，1960，猪貴義ほか，1987）。一般に高い気温の 時は身体からの放熱を盛んにするために体表面積 をできるだけ大きくしょうとし，また，気温の低 い時は体表面積をできるだけ小さくし，放熱を最 小限にとどめようとすると言われている。なお， フロリダ州のマイアミ市の年平均気温は 24.3 度 で, 東京都の年平均気温は15.6度で(国立天文台, 1992), 福州市の年平均気温はマイアミ市と東京都 の中間である(中華人民共和国全資料編集委員会, 1986). 年平均気温は東京よりフロリダ州マイアミ 市の方が 9 度近く高かったにもかかわらず, 全般 に米国人男子の方が日本人男子に比べ皮下脂肪厚 は厚い傾向にあった(石田, 1994)。従って, 気候 的要因はそのまま体組成に影響を及ぼし，生物学 的, 生理学的な反応をもたらしているとは限らな い. 現代都市の生活のなかは, 冷暖房が普及して きていて,一年中あまり変化のない気温の中で暮 らすことができる，つまり，人間は環境に対する 生物的適応, 生理的適応を持っているわけでなく, 行動的適応，さらに文化的適応を持っているとい える.したがって, 運動や食事を含む生活習慣の 影響，およびそれらと遺伝との交互作用について 検討していく必要があろう。

近赤外分光法による本研究の被検者の平均体脂 肪率は11.8\%であるが，これは蒲田ほか（1991） が長崎大学で男子65名を対象に近赤外分光法で測 定した体脂肪率の值 $12.9 \%$ とほほ一致している。
これは, BFT-2000に内蔵された体脂肪率の推定 式（沢井ほか，1990）が平均年齢30歳弱の正常体 重者（平均の体脂肪率：14\%）をもとに作成され ており, 本研究の被検者の年齢および体型の特徵 とよく似ているので, 本研究の被検者にもある程 度当てはまるのではないかと思われる。しかし， 母集団である福州市の成人男子について妥当性の 検討はなされていないため, この推定式が適当か どうかは判断できない。そそれ故，中国人を対象と した脂肪率推定式の開発も必要と思われる。

体脂肪率及び体脂肪量と, 身体的特徴および皮 下脂肪厚の測定値の相関分析の結果から, 体脂肪 量と皮下脂肪厚の相関係数は 0.34 から $0.70 て ゙$, 正 の相関がみられたが,それほど強いものではない。 これは, 前述した近赤外分光法の妥当性の問題の 他, 体脂肪量は皮下脂肪量と体内深部脂肪量の二 つの部分で構成され, 体脂肪量が大きければ必ず しも皮下脂肪量も大きいとは言い切れず, 体内深 部脂肪量にも左右されることが原因ではないかと 思われる。

\section{V 結 論}

成人男子の皮下脂肪厚分布を調べるため，中国 福州市第二病院に勤務している成人男子55名を対 象に, 身長, 体重のほか, B-mode 式超音波を用い て四肢として右側の上腕後部, 大腿前部, 下腿後 部の 3 部位と体幹として肩甲骨下部, 腹部, 腸骨 棘上部の 3 部位計 6 部位の皮下脂肪厚を測定し た. 近赤外分光法体脂肪測定器として BFT2000 （ケット科学研究所）を用いて，体脂肪率を 推定した。 また, 本研究の 20 歳代の被検者の結果 と日本及び米国の研究の結果を比較した。その結 果, 以下の点が明らかとなった。

(1) 本研究の対象の皮下脂肪厚は腹部が最も厚 く, 肢体が薄いという分布パターンはこれまでの 日，米の報告と一致している．日本および米国の 研究結果と比較したところ, 本研究の被検者の皮 下脂肪厚の分布は日, 米の研究の結果より腸骨棘 上部, 下腿後部が有意に大きく, 肩甲骨下部の方 が有意に小さい值であった。 
(2) 近赤外分光法による体脂肪率及び体脂肪量 は，皮下脂肪厚との間に強くはないが，ある程度 の正の相関がみられた。この理由として，近赤外 分光法体脂肪測定器の妥当性の他, 体脂肪量は必 ずしも皮下脂肪の量と一致するとはいいきれず， 体内深部脂肪にも左右されることが考えられる.

謝辞: 本研究の実施にあたって, 終始御指導を頂き ました東京大学教育学部健康教育学研究室現在神戸大 学発達科学部健康発達論講座の東郷正美教授に深く感 謝いたします。

\section{文献}

Kissebah, A.H., Vydelingum, N. \& Murray, R. (1982): Relation of body fat distribution to metabolic complications of obesity, J. Clin. Endocrinol. Metab, 54, 254-260

福永哲夫, 他（1990）：現代の体育・スポーツ科学, 日本人の体肢組成，12-46，朝倉書店 (東京)

保志 宏(1989)：生体の線計測法，277-281，てらぺ いあ(東京)

猪 貴義(1987)：動物の成長と発育, 182-183，朝倉 書店 (東京)

石田良恵，金久博昭，伊東輝雄，他（1989）：成人男 女筋厚抢よび皮下脂肪厚, 第 9 回日本肥満学会記録, $221-223$

石田良恵（1994）：超音波断層法による身体組成の加 齢変化にみられる日米比較, 民族衛生，60 (4), 212222

伊藤広三 (1960)： 学齢期体重の季節変動に関する研 究, 生物統計学雑誌, 8 (3), 69-77

市川伸一，大橋靖雄 (1987)：SASによるデー夕解析 入門, SAS で学ぶ統計的デー夕解析 1, 101-178, 東 京大学出版会 (東京)

Desprès, J.P., Moorjani, S., Lupien, P.J., et al. (1990): Regional distribution of body fat, plasma lipoproteins, and cardiovascular disease, Arteriosclerosis, 10, 497-511

蒲田秀子, 大塚健作, 西山久美子, 他 (1991)： 近赤 外線法と水中体重法による体脂肪率の比較研究, 長
崎大学医療技術短期大学部紀要， 5, 15-22

国立天文台 (1992)：理科年表，199，317，311，丸善 株式会社(東京)

Rebuffè-Scrive, M., Andersson, B., Olbe, L., et al. (1989): Metabolism of adipose tissue in intraabdominal depots of nonobese men and women, Metab, 38 (5), 453-458

大野 誠 (1992)： 糖尿病の新しい検査測定機器(4)体 脂肪測定法の原理と簡易式体脂肪測定法の有用性に ついて, Diabetes Frontier, 3 (4), 409-416

Pierson, R.N.J., Wang, J., Aulet, M., et al. (1990) : Race, sex, age, and fatness affect waist hip ratio in normal Asians, Blacks, and Caucasians, Int. J. Obesity, 14 (Suppl. 2), 103

廖 恵珍, 徐 蘊芹 (1991)：福建省食物栄養結構中 長期目標探討，中国公共衛生， 7 (8), 345-347

Fujioka, S., Matsuzawa, Y., Tokunaga, K., et al. (1987) : Contribution of intraabdominal fat accumulation to the impairment of glucose and lipid metabolism in human obesity, Metab, 36, 54 $-59$

沢井史穂，白山正人，武藤芳照，他（1990）：近赤外 文光法による体脂肪測定, 体力科学, 39, 155-163

Rognun, T.O., Rokahl, K. \& Opstad, P.K. (1982) : Regional differences in the lipolytic responses of the subcutaneous fat depors to prolonged exercese and severe energy deficiency, Eru. J. Appl. Physio, 49, 401-408

中華人民共和国全資料編集委員会（1986）：中華人民 共和国全資料，500，日中親善促進協(東京)

中国学生体質与健康研究組編 (1993)：1991年中国学 生体質与健康監測報告, 79-111, 北京科学技術出版 社 (北京)

Ishida, Y., Carroll, J.F., Pollock, M.L., et al. (1992) : Reliability of B-mode ultrasound for the measurement of body fat and muscle thickness, Am. J. Hum. Biol, 4, 511-520

湯浅景元, 福永哲夫（1987）：超音波法による皮下脂 肪厚分布パターン, 体力科学, 36, 36-41

（受稿 1995.1.31；受理 1995.7.7） 